\title{
THE IMPACT OF INTERCULTURAL COMMUNICATION COMPETENCE ON SERVICE QUALITY AND CUSTOMER SATISFACTION*
}

\author{
İsmet GÜNEŞ 1 \\ Fauziah Sh. AHMAD ${ }^{2}$
}

\begin{abstract}
The article aims to better understand the impact of intercultural communication competence on personal interaction and customer satisfaction in grocery retail industry. The study explored three major constructs namely intercultural communication competence, personal interaction which is one of the important variables for service quality and customer satisfaction of major grocery retail outlets (e.g. supermarkets and hypermarkets) in Klang Valley area, Malaysia. The customer based approach methodology was adopted and the data was collected using structured questionnaire survey. The measurement of the constructs and their interrelationships were examined based on structural equation modelling approach. Based on the proposed framework, a number of propositions were developed to facilitate empirical research on intercultural communication competences of staff comprises of inter-role congruence and interaction comfort as perceived by customers of the selected grocery retail outlets. This contributes to the development of a theory based path model, which links the intercultural competence to service quality and customer satisfaction. Although numerous researchers have studied the extensive topic of service quality and customer satisfaction, none of those studies explored the critical role of intercultural communication competence and integrated the construct in their service quality and customer satisfaction model. Since intercultural notions are becoming acknowledged as crucial to success particularly in multicultural society, an inclusive dimension of the key determinants of the factor should improve our understanding of this phenomenon and provide an impetus for future research.
\end{abstract}

Keywords: Intercultural communication competence, customer satisfaction, retailing and service quality.

\footnotetext{
${ }^{*}$ Bu makale daha önce yayımlanmamıştır.

${ }^{1}$ Araş. Gör., Celal Bayar Üniversitesi, İktisadi ve İdari Bilimler Fakültesi, İktisat Bölümü, ismet.gunes@cbu.edu.tr.

${ }^{2}$ Assoc. Prof. Dr., University Teknologi Malaysia, International Business School, Kuala Lumpur-Malaysia, fsa@ibs.utm.my.
} 


\title{
KÜLTÜRLERARASI İLETISŞIM KABÍLIYYTIININ HIZMET KALITTESINE VE MÜŞTERI MEMNUNIYETINE ETKISİ
}

\begin{abstract}
ÖZ
Bu makalede, supermarket perakendeciliği sektöründe kültürlerarası iletişim yetkinliğinin kişisel etkileşim ve müşteri tatmini üzerindeki etkisinin daha iyi anlaşılması hedeflenmektedir. Çalışma üç temel kuramı incelemektedir; kültürlerarası iletişim yetkinliği ve Malezya'nın Klang bölgesindeki önde gelen supermarket perakendecilerinde hizmet kalitesi ve müşteri tatmini adına önemli değişkenlerden biri olan kişisel etkileşim. Bu çalışmada müşteri temelli yaklaşım metodolojisi kullanılmış ve veri, yapılandırılmış anket yöntemi kullanılarak toplanmıştır. Kuramların ve kuramlar arası ilişkilerin ölçümü yapısal eşitlik modeli ile gerçekleștirilmiştir. Önerilen model kapsamında, çalışanların kültürlerarası iletişim yetkinlikleri üzerinde ampirik araștırma yapmayı kolaylaştıracak bir takım öneriler geliştirilmiştir; roller arası uyumluluk ve seçilmiş supermarket perakendecilerinin müşterileri tarafindan algılandığı biçimiyle etkileşim rahatlığı gibi. Bu, hizmet kalitesi ve müșteri tatminini kültürlerarası yetkinliğe bağlayan teori modelli bir path modeli oluşturmaya katkı sağlamaktadır. Hizmet kalitesi ve müşteri tatmini konusunu çalışan çok sayıda araștırmacı olmasına karşın, bu araştırmacılardan hiçbiri kültürlerarası iletişim yetkinliğinin kritik rolünü incelememiş ve bu kuramı, hizmet kalitesi ve müşteri tatmini modeline entegre etmemiştir. Kültürlerarası kavramların özellikle çok kültürlü toplumlarda başarı için kritik önem arz eden unsurlar olarak kabul edilmeye başlanmaslyla birlikte, bu faktörün temel belirleyicilerinden olan kapsayıcı bir boyut olguyu kavrayışımıza katkı ve gelecek çalışmalara bir ivme kazandırmalıdır.
\end{abstract}

Anahtar Kelimeler: Kültürler arası iletişim kabiliyeti, müşteri memnuniyeti, perakendecilik ve hizmet kalitesi.

\section{Introduction}

Intercultural communication competence (IC) which deals with having the right mind set, skill and sensitivity when managing in cross-cultural situations (Sharma et al., 2009) has become a new area of focus amongst marketers in ensuring customer satisfaction (CS). CS on the other hand is significant to enduring business success and one of the most frequently examined notions in the context of marketing (Kuo et al., 2009). CS with highly satisfied service quality (SQ) has been recognised as an important factor for characteristic of long-term business success, improved customer retention, positive word of mouth, increased profitability and sustainable competitiveness. Most of the studies involving the CS variable investigates its relationship with customers' pre or postconsumption evaluations such as behavioural and attitudinal loyalty

52 | Celal Bayar Üniversitesi Sosyal Bilimler Dergisi - Cilt: 13, Sayı: 2, Haziran 2015 
(Souiden and Pons, 2009) as well as SQ in various settings (Kuo et al., 2009).

Despite the general acceptance on the important of IC particularly for firms operating in diverse cultural settings, most of the existing discussions are theoretical and qualitative based. The gap exists in providing empirical evidence on the relationships between IC, Personal Interaction (PI) and CS particularly in a specific industry type that operates in cross-cultural environment. Although, many authors (Sharma et al., 2009; Friedman and Antal, 2005) suggest that measurement of SQ for service settings in multicultural societies shall include cultural dimension for more credible outcomes existed models do not include culture as a factor or dimension.

In order to meet the research goals, the study a theoretical based model of the relationships among these three constructs. This study particularly examines IC in terms of inter-role congruence (IC4) and interaction comfort (IC1, IC2 and IC3) as indicated at the Table 2. It also examines the PI aspect of SQ, which is earlier developed by Dabholkar et al. (1996). The dimension of CS is based on product quality (CS1 and CS2), product assortment (CS3) and price (CS4). According to the proposed framework, PI mediates the impact of IC on CS. The validity and reliability of the constructs are established in the measurement model through confirmatory factor analysis and the structural equation modeling evaluates interrelationships among the constructs.

The remainder of this study is organized as follows. Following this introduction, the study presents literature review and develops the hypothesised relationships among the constructs of the proposed model. The methodology of the model is then represented. This is followed by a presentation of the research findings as well as their implications.

\section{Literature Review}

A. Intercultural Communication Competence

IC is defined as the capability to think, discriminate the differences, internalize the various cultural settings, manage the experiences properly and build an effective communication in the most appropriate way with individuals from different cultures in the cross-cultural environment (Friedman and Antal, 2005). IC influences cross-cultural interactions (Sharma et al., 2009) where people with better IC represent a greater ability to learn foreign languages and norms or values of other cultures.

They can communicate effectively with people from different cultural backgrounds (Lustig and Koester, 2009; Thomas et al., 2008). Furthermore, service attentiveness, revenue contribution, 


\section{İsmet Güneş-Fauziah Sh. Ahmad}

interpersonal skills, job and social satisfaction are influenced by employees' level of intercultural sensitivity (Sizoo et al., 2005), and although there is a positive link between IC and CS score (Sharma et al., 2012), most of the customer expectations and reactions have examined without IC (Ryoo, 2005).

Individuals with lower IC are likely to feel less comfortable and expose weak inter-role congruence in intercultural service encounters (ISEs) compared to those with higher levels of IC (Friedman and Antal, 2005). These with higher IC exhibit more empathy and respect for individuals from other cultures, respond to curious circumstances and behaviours in a non-judgmental way without showing visible or perceivable discomfort, and enthusiastically use their knowledge and experience to predict various expectations in numerous situations (Lustig and Koester, 2009). Earlier studies in sociology, psychology and marketing have provided several appropriate reasons of increasing customer interaction comfort during service experience have a positive impact on CS (Paswan and Ganesh, 2005), elimination of perceived risk, trust and confidence (Spake et al., 2003).

According to Lustig and Koester (2009), most of the people do not care the ethnographic background of others from different cultures and tend to internalize their behavioural norms that are related to cultural aspects as correct and appropriate. Therefore, interactions are crucial to reduce any possible discomforts due to perceived dissimilarities in behavioural norms. In terms of ISE, an achievable outcome may be more likely if cultural background of a service employee's (e.g., physiognomy, demeanour, language, communication, and style) is perceived to be familiar to cultural background of a customer's.

For instance, a lack of awareness on numerous elements of each other's culture related to key service features such as serving with a smile and touching or non-touching, may result in deeply misunderstanding and dissatisfaction compared to ISEs within one's own culture. Therefore, when ISEs share common values, language and norms, the predictability of their behaviour improves, the communication becomes easier and understanding the role expectations from each others (Wigley and Rachel Chiang, 2009; Kong and Jogaratnam, 2007).

Several social or psychological theories have used to describe the behaviour of customers and employees in cross-cultural environment. According to the theory of interdependence (Surprenant et al, 1983), each part of interaction has an impact on

54 | Celal Bayar Üniversitesi Sosyal Bilimler Dergisi - Cilt: 13, Sayı: 2, Haziran 2015 
another part because the behaviour of the second part is influenced by the outcomes of the first part.

A favourable service outcome depends on role clarity that is identified, as their both sides of interactions (customer and employee) understand each other's role in society, expectations and perceptions (Solomon et al., 1985). Unfortunately, even in ISE of similar cultures, they may have dissimilar perceptions and expectations about each other, or they may not always allow with their role in society (Baker et al., 2009). As highlighted in the role theory (Solomon et al., 1985), the level of conflict that is caused by the role clarification (the degree of understanding and agreement between both sides on each other's role in an interaction) may involve breaking the communications and confusion due to a dissatisfied service experience.

Thus, ISEs from unfamiliar cultures may not approve and understand each other's service roles and expectations due to dissimilarity, whereas customers from similar cultures may recognise and approve with each other's role to a better extent. Table 1 represents several previous studies related to the intercultural context in the marketing.

Table 1. Intercultural Conceptualizations in the Marketing Literature

\begin{tabular}{|l|l|l|}
\hline Author & Concept & \multicolumn{1}{|c|}{ Definition } \\
\hline $\begin{array}{l}\text { Sharma } \text { et }(2009) \\
\text { Intercultural }\end{array}$ & $\begin{array}{l}\text { "This article presents a conceptual } \\
\text { framework for intercultural service } \\
\text { encounters applicable to both customers } \\
\text { and employees." (p. 227) }\end{array}$ \\
\hline $\begin{array}{l}\text { (2009) } \text { et al. } \\
\text { Intercultural }\end{array}$ & $\begin{array}{l}\text { "This paper aims to report a study that } \\
\text { focuses on the moderating role of } \\
\text { involvement in the relationships between } \\
\text { customer contact employees' customer } \\
\text { orientation and service quality perceptions } \\
\text { and satisfaction." (p.115) }\end{array}$ \\
\hline Reimann et & Intercultural \\
\hline
\end{tabular}




\section{İsmet Güneş-Fauziah Sh. Ahmad}

\begin{tabular}{|c|c|c|}
\hline al. (2008) & & $\begin{array}{l}\text { cultural differences in the context of } \\
\text { business-to-business relationships." } \\
\text { (p.63) }\end{array}$ \\
\hline $\begin{array}{l}\text { Thomas et } \\
\text { al. (2008) }\end{array}$ & Intercultural & $\begin{array}{l}\text { "In this article, we develop a } \\
\text { conceptualization of cultural intelligence } \\
\text { that addresses a number of important } \\
\text { limitations of previous definitions." (p.123) }\end{array}$ \\
\hline $\begin{array}{l}\text { Kong and } \\
\text { Jogaratnam } \\
(2007)\end{array}$ & Intercultural & $\begin{array}{l}\text { "This research extends previous work by } \\
\text { examining cross-cultural differences and } \\
\text { intends to provide a better understanding } \\
\text { of restaurant customers in the USA and } \\
\text { Korea, as well as to enable restaurant } \\
\text { operators and managers to better service } \\
\text { their clientele in the global marketplace." } \\
\text { (p.275) }\end{array}$ \\
\hline $\begin{array}{l}\text { Friedman } \\
\text { and Antal } \\
(2005)\end{array}$ & Intercultural & $\begin{array}{l}\text { "This article offers an alternative approach } \\
\text { to intercultural competence, 'negotiating } \\
\text { reality', that engages cultural conflict as a } \\
\text { resource for learning." (p.69) }\end{array}$ \\
\hline $\begin{array}{l}\text { Sizoo et al. } \\
(2005)\end{array}$ & Intercultural & $\begin{array}{l}\text { "This study proposes adding to that trend } \\
\text { by attempting to measure the effect of } \\
\text { intercultural sensitivity on the cross- } \\
\text { cultural performance of service } \\
\text { employees." (p.245) }\end{array}$ \\
\hline $\begin{array}{l}\text { Ryoo } \\
(2005)\end{array}$ & Intercultural & $\begin{array}{l}\text { "This study presents an in-depth analysis of } \\
\text { talk between Korean immigrant }\end{array}$ \\
\hline
\end{tabular}

56 | Celal Bayar Üniversitesi Sosyal Bilimler Dergisi - Cilt: 13, Sayı: 2, Haziran 2015 
The Impact of Intercultural Communication Competence...

\begin{tabular}{|c|c|c|}
\hline & & $\begin{array}{l}\text { shopkeepers and their African-American } \\
\text { customers in service encounters." (p.79) }\end{array}$ \\
\hline $\begin{array}{l}\text { Paswan } \\
\text { and } \\
\text { Ganesh } \\
\text { (2005) }\end{array}$ & Intercultural & $\begin{array}{l}\text { "This study empirically investigates the } \\
\text { notion of being comfortable with social } \\
\text { interaction in a foreign country (interaction } \\
\text { comfort) and its impact on how service } \\
\text { quality is evaluated." (p.93) }\end{array}$ \\
\hline $\begin{array}{l}\text { Hopkins et } \\
\text { al. (2005) }\end{array}$ & Intercultural & $\begin{array}{l}\text { "The value of this paper is that it uses } \\
\text { cultural identity theory to extend an } \\
\text { existing model that examines the nature } \\
\text { and determinants of customer expectations } \\
\text { of service." (p.329) }\end{array}$ \\
\hline
\end{tabular}

\section{B. Service Quality}

Providing high-quality service is reflected to be a crucial strategy for success and endurance in today's competitive environment (Parasuraman et al., 1985), and has thus become part of the basic strategy in retailing (Martínez- Ruiz et al., 2011). SQ has been defined as "the consumer's overall impression of the superiority of the organization and its service encounters" (Bitner and Hubbert, 1994).

The previous literature recommends that there are two different schools of thought on how to conceptualize or operationalize perceived quality. The first perspective is influenced by Nordic school of thought and the model, proposed by Gro"nroos (1984), is based on the two-constructs. The constructs of model are namely technical quality that refers to the service performance's outcome; the second dimension, functional quality that refers to the subjective perception of how the service is delivered, which includes customer perceptions during transactions. Furthermore, Rust and Oliver (1994) added a dimension as a third to the model and suggested three aspects of SQ: service product (parallel to technical quality), service delivery (related to functional quality) and service environment (as a new). The implication of this model is that it stresses the significance of understanding customer expectations and 
perceptions that meets customers' expectations (Omar and Musa, 2011). Parallel to the Nordic model, the SERVQUAL model established by Parasuraman et al. (1988) is based on the expectations disconfirmation approach. The scholars recognised five main dimensions of SQ across a service industries: tangibles, reliability, responsiveness, assurance and empathy. However, this approach criticized by Caro and Garcia (2007); Dabholkar et al. (1996); Babakus and Boller, (1992); Bouman and Van Der, (1992). The main reason for the criticism is the overrated on customer's expectations in comparison to their perceptions (Wall and Payne, 1973) and the data quality is influenced by confusion due to the realization of $\mathrm{E}$ (expectation) and $\mathrm{P}$ (perception) version (Bouman and Van Der, 1992). According to the model, achievable SQ means that the perceptions of customers (actual performance) meet or exceed their expectations of what the service settings should provide. Concluded in depth interviews and discussions of focus groups with service settings in four different service industries, Parasuraman et al. (1985) identified five determinants of SQ as indicated at the table 2 .

Although, the model has been widely used in different service contexts, however, the SERVQUAL scale does not match the specific requirements of the retailing (Dabholkar et al., 1996). For instance, Dabholkar et al. (1996) and Babakus and Boller, (1992), used SERVQUAL scale for evaluating the SQ in the retail stores, however they determined that the scale is not applicable for the retailers without any industrial adaptation. In order to fill this gap in the literature, Dabholkar et al. (1996) developed and empirically validated retail service quality scale (RSQS) that is the sectormodified model for retailing. This instrument also captures that are likely to be shared by pure service and retail environments, additional dimensions of RSQS relevant to the retail environment (Caro and Garcia, 2007; Babakus and Boller, 1992).

According to Dabholkar et al. (1996), RSQS has three levels that are namely a dimensional, an overall, and a sub-dimensional level and they established the model under five dimensions- personal interaction, physical aspects, reliability, policy and problem solving as indicated at table 2 . RSQS also is involved total 28-item, and 17 item of the model have been adopted by SERVQUAL scale and rest of them have been developed or added based on the recent literature review and qualitative research.

58 | Celal Bayar Üniversitesi Sosyal Bilimler Dergisi - Cilt: 13, Sayı: 2, Haziran 2015 


\section{Customer Satisfaction}

Satisfaction with services is a critical instrument for understanding the path of the retailer's success in the market (Martínez- Ruiz et al., 2011). CS is one of the most studied topics in the marketing context. Specifically, a review from these studies, interrelationship among service evaluation, loyalty and other related topics with cultural aspects have become competitive power for the retailers (Wang et al., 2010; Wigley and Rachel Chiang, 2009; Ihtiyar and Ahmad, 2012). For instance, CS reduces the costs for dealing with poor quality and attracting new customers, defects complaints (Ladhari, 2009). Reflecting these benefits, CS has been found to have positive impact on loyalty (Omar and Musa, 2011), be applicable predictor for purchase intention (Kuo et al, 2009), and relationship with culture (Chan and Wan, 2008).

\section{Interrelationship Among IC, PI and CS}

The function of services in the world economy has increased dramatically within the past decade, especially among the developed countries. In industrialized countries, services have replaced goods and the ability to choose from various dealers provides customers superior power and challenges of service providers to do their very best to satisfy their demands and requests; however, service providers that have organizations in different countries have been challenging to create an efficient and stable marketing orientation (Martínez-Ruiz et al., 2011; Wigley and Rachel Chiang, 2009). Therefore, driven by the recent growth pace of internationalization of service providers, a number of studies have investigated the varying perceptions of SQ (Paswan and Ganesh, 2005), CS (Kuo et al., 2009; Reimann et al., 2008), purchase intention (Souiden and Pons, 2009), loyalty (Omar and Musa, 2011), service encounters (Kong and Jogaratnam, 2007; Sizoo et al., 2005), and related aspects in the context of culture.

The rationale of these studies in various areas within the context of intercultural issues of marketing is analysing, demystifying and improving the consistent solutions that are faced common problems by retailers in the multicultural society (Prasad and Aryasri, 2011; Chan and Wan; 2008). The cognitive inferences of the numerous implementations in practical and/or theoretical fields of these studies present that intercultural context are becoming a critical construct in the marketing (Martínez-Ruiz et al., 2011; Wang et al., 2010; Souiden and Pons, 2009; Lustig and Koester 2009; Baker et al., 2009). The retailers may persist to follow this strong change, otherwise; external factors that are not controlled by the grocery retailers may shape the market. Even for the retailers that have not 


\section{İsmet Güneş-Fauziah Sh. Ahmad}

plans to leave their home country for investing another country, there are obvious, efficient and precisely rule to understanding the perspectives of their local customers who have different cultural backgrounds (Reimann et al., 2008).

The conceptualization covers indicators of SQ mainly in the local market. When applied to global market, however, the model needs to incorporate the possible impact of intercultural differences. Customers in various cultures in a country may have different levels of service expectations and perceptions on CS, because cultures differ in their patents behaviour and attitudes (Prasad and Aryasri, 2011).

The SQ literature has investigated the effect of culture on CS or related topics of marketing. In contrast, the role of ISEs interaction during service experiences has usually received comparatively little research consideration (Ladhari, 2009). More recently, it has become progressively recognised that interactions of customers and employees have a significant influence on CS (Prasad and Aryasri, 2011). Furthermore, particularly, heightened awareness of the role of culture and its impact on the PI and its total impact on CS has been ignored in customer behaviour studies.

In terms of those aspects, this research is conducted a study to relate PI with culture and its impact on CS. In particular, the research examined how the level of PI and CS are influenced by IC. Understanding the level of interaction of ISEs is critical in determining the minimum quality of service delivery.

Eventually, the scholars or practitioners may not disregard the effect of intercultural issues on SQ and CS. As, indicated on the relevant part of the article, the level of IC may highly relate the PI and both influence CS in the buying process, as a domino effect.

Hypothesis 1. Personal interaction has a positive impact on customer satisfaction.

Hypothesis 2. Intercultural communication competence has a positive impact on personal interaction.

Hypothesis 3. Intercultural communication competence has a positive impact on customer satisfaction.

\section{E. Grocery Retail Industry of Malaysia}

According to the last census in 2010 (Statistics Department of Malaysia), Malaysia's population was 28.3 million and Malaysia was the 17th crowded country throughout the Asia and the 42th most crowded country in the World. Over $60 \%$ of the population of Malaysia is regarded as middle-income customers, and poverty has virtually been eliminated. Over $70 \%$ of the population of Malaysia now lives in the urban areas (Cottrell et al., 2010). These figures might be a deductive and explicable reason for investing in the food 
retail industry of Malaysia by global players. However, the market has not been identified as easy in or easy out. Malaysia's food retail industry has highly dynamic and competitive market structure.

Furthermore, well-know western global player such as; Tesco (45) have been challenging eastern or domestic brands such as; Mydin (94), Giant (147), AEON-JUSCO (45) etc. and creating new strategies for increasing their market share against the domestics companies in the market.

According to (PWC, 2011), the turnover of the sector increased to $\$ 54$ billion dollars at the period of 2010 from $\$ 48$ billion at 2009. Furthermore, the expected growth percentages between 2010 and 2012 are between 5\% and 6\%. As in the world, the sectorial growth rate of retail industry in Malaysia will be represented a increase in the next years and annual the growth rate of the industry is $3.7 \%$ and $3.8 \%$ per annum in 2013-2014 (PWC, 2011).

\section{Research Methodology}

\section{A. Data collection}

The study examines impact of IC on PI and CS of Malaysian grocery retail outlets in Selangor, Malaysia. The study was conducted in 2012 using appropriate method of collecting data from Malaysian respondents by self-administered questionnaires. From this population, among the sample for the study was chosen based on suitable sampling (Huddleston et al, 2009). Although, several reminders were sent to the potential respondents, to improve the participation, only 227 usable feedbacks were received by the cut-off date and about eight of the returned surveys were not appropriate for the analysis. This represented about $73.24 \%$ of total 299 e-mail and mail invitations have been sent.

Likert-type scale was applied in previous studies to the questionnaire design, running from 7 (very high) to 1 (very low) (Kong and Jogaratnam, 2007). Before the distribution of the questionnaire, a pilot test was performed for normality check, readability, accuracy, comprehensiveness and further item purifications appropriately. Base on the feedbacks of pre-test, few items were rephrased for a comfortable reading and answering the survey.

\section{Findings and Discussion}

\section{A. Demographics}

A majority (72.7\%) of the participants were male. In terms of income, $51.2 \%$ of the participants had a monthly income of less than $\$ 1,000,21.1 \%$ had a income as monthly that is between $\$ 1,000$ $\$ 1,333$, and $24.7 \%$ incomes' more than $\$ 1,334$. The education 
indicators as, $90.7 \%$ of the respondents had a degree, $7.90 \%$ had a diploma, and $1.30 \%$ had a high school education. More than $58 \%$, $5.70 \%, 7 \%$ and $18.5 \%$ of them are Malay, Chinese, Indian and others respectively. $78.9 \%$ of respondents are purchasing maximum five times in a month and more than $41 \%$ of respondents are paying between $\$ 34-\$ 66$ for purchasing in one time.

\section{B. Measurement Model Evaluation}

The measurement theory assessment of SEM analysis for the model is based on the revised number of items as mentioned in appendix 1 after removing those with weak factor loading scores from confirmatory factor analysis (CFA).

Table 2. Items and Its Sources

\begin{tabular}{|c|c|}
\hline Questions & Sources \\
\hline \multicolumn{2}{|l|}{ Service Quality } \\
\hline $\begin{array}{l}\text { Behaviour of store employee instils confidence in } \\
\text { customers. (PI1) } \\
\text { The employee has sufficient knowledge to attend to } \\
\text { customers. (PI2) } \\
\text { The store employee consistently courteous with customers. } \\
\text { (PI3) } \\
\text { The store employee gives prompt service to customer. (PI4) }\end{array}$ & $\begin{array}{l}\text { Dabholkar et } \\
\text { al. (1996) }\end{array}$ \\
\hline \multicolumn{2}{|l|}{ Customer Satisfaction } \\
\hline $\begin{array}{l}\text { This store has good quality merchandise. (CS1) } \\
\text { This store offers products with excellent features. (CS2) } \\
\text { This store has the right merchandise selection. (CS3) } \\
\text { This store provides a good value for money. (CS4) }\end{array}$ & $\begin{array}{l}\text { Hudleston et } \\
\text { al. (2009) } \\
\text { Moliner et al. } \\
\text { (2007) } \\
\text { Pappua and } \\
\text { Questerb } \\
\text { (2006), }\end{array}$ \\
\hline \multicolumn{2}{|l|}{ Intercultural Competence } \\
\hline $\begin{array}{l}\text { I am comfortable to staff who is of different ethnicity than } \\
\text { mine. (IC1) } \\
\text { I think the store is well-associated and adapted to local } \\
\text { culture. (IC2) }\end{array}$ & $\begin{array}{l}\text { Sharma et al. } \\
\text { (2009) } \\
\text { Briones et al. } \\
\text { (2009) }\end{array}$ \\
\hline
\end{tabular}

62 | Celal Bayar Üniversitesi Sosyal Bilimler Dergisi - Cilt: 13, Sayı: 2, Haziran 2015 
I usually handle culture transitions very well. (IC3) Dodd (1998)

The store staffs behave accordingly within their expected role. (IC4)

CFA analysis, the Kaiser-Meyer-Olin (KMO) measure of sampling adequacy, Barlett's test of sphericity and Cronbach $\boldsymbol{\alpha}$ test for reliability are conducted and represented in Table 3.

Table 3. Factor Analysis

\begin{tabular}{|c|c|c|c|c|c|}
\hline Constructs & \multicolumn{3}{|c|}{ Bartlett's Test } & KMO & Cronbach $\boldsymbol{\alpha}$ \\
\hline Personal Interaction & $\mathbf{\chi 2 = 3 7 2 , 4 4 7}$ & $\mathrm{df}=6$ & Sig. $<0.001$ & .780 & .847 \\
\hline Customer Satisfaction & $\mathbf{\chi 2 = 4 2 4 , \mathbf { 8 0 0 }}$ & $\mathrm{df}=6$ & Sig. $<0.001$ & .825 & .871 \\
\hline Intercultural & $\mathbf{\chi 2 = 1 8 7 , 8 6 0}$ & $\mathrm{df}=6$ & Sig. $<0.001$ & .771 & .748 \\
\hline Overall & & & & & .880 \\
\hline
\end{tabular}

Table 4 represents the standardised loadings scores of each variable of the latent constructs and good fit indices for CFA analysis to warrant the appropriateness to proceed with structural measurement. The Comparative Fit Index (CFI) of .971 and Tucker Lewis Index (TLI) of .962 reveal the good fit of incremental index for this analysis while the Root Mean Square Error of Approximation (RMSEA) of .055 represents the satisfactory absolute fit index.

\section{Structural Equation Modelling}

With good CFA outcome, the analysis proceeds with structural measurement. The fit indices and their characteristics for establishing acceptable fit for the analysis are represented in Table 4. According to Hair et al. (2006), the fit analysis must include one incremental index and one absolute index in addition to chi-square $\chi^{2}$ value and the associated freedom degree. Figure 2 indicates the fitted research model that represents the acceptable goodness-of-fit indices. The standardised parameter estimates and significant values.

As highlighted in Table 4, chi-square $\chi^{2}$ is significant with ratio of $\chi^{2} / \mathrm{df}$. The TLI incremental fit index, the CFI goodness of fit index and RMSEA absolute fit index also performed perfectly for the structural model. 


\begin{tabular}{|c|c|c|c|c|c|c|}
\hline \multicolumn{7}{|c|}{ Table 4. Regression Weights } \\
\hline & & Estimate & S.E. & C.R. & $\mathrm{P}$ & Label \\
\hline PI & \begin{tabular}{l|l}
$<--$ & IC
\end{tabular} & .521 & .105 & 4.985 & $* * *$ & \\
\hline $\mathrm{CS}$ & \begin{tabular}{l|l}
$<--$ & PI
\end{tabular} & .287 & .071 & 4.044 & $* * *$ & \\
\hline $\mathrm{CS}$ & $<---\quad$ IC & .750 & .110 & 6.821 & $* * *$ & \\
\hline $\mathrm{PI} 4$ & \begin{tabular}{l|l}
$<--$ & PI \\
\end{tabular} & 1.000 & & & & \\
\hline PI3 & \begin{tabular}{l|l}
$<--$ & PI \\
\end{tabular} & .944 & .084 & 11.204 & $* * *$ & \\
\hline $\mathrm{PI} 2$ & \begin{tabular}{l|l}
$<--$ & PI
\end{tabular} & 1.008 & .087 & 11.540 & $* * *$ & \\
\hline PI1 & \begin{tabular}{l|l}
$<--$ & PI \\
\end{tabular} & .904 & .086 & 10.356 & $* * *$ & \\
\hline IC1 & \begin{tabular}{l|l}
$<---$ & IC \\
\end{tabular} & 1.000 & & & & \\
\hline IC2 & \begin{tabular}{l|l}
$<--$ & IC \\
\end{tabular} & 1.124 & .130 & 8.633 & $* * *$ & \\
\hline IC3 & \begin{tabular}{l|l}
$<--$ & IC \\
\end{tabular} & .903 & .123 & 7.334 & $* * *$ & \\
\hline CS1 & \begin{tabular}{l|l}
$<--$ & CS \\
\end{tabular} & 1.000 & & & & \\
\hline CS2 & \begin{tabular}{l|l}
$<--$ & CS \\
\end{tabular} & 1.016 & .072 & 14.095 & $* * *$ & \\
\hline $\mathrm{CS} 3$ & \begin{tabular}{l|l}
$<--$ & CS \\
\end{tabular} & .924 & .075 & 12.350 & $* * *$ & \\
\hline $\mathrm{CS} 4$ & \begin{tabular}{l|l}
$<--$ & CS \\
\end{tabular} & .875 & .075 & 11.695 & $* * *$ & \\
\hline IC4 & \begin{tabular}{l|l}
$<--$ & IC \\
\end{tabular} & .974 & .138 & 7.079 & $* * *$ & \\
\hline
\end{tabular}

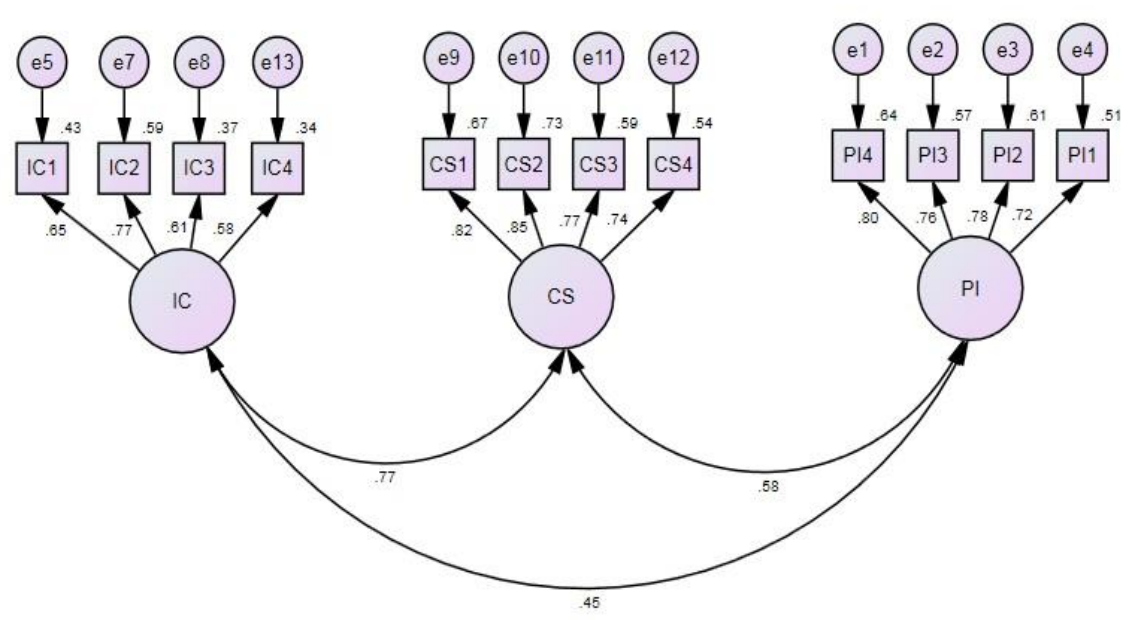

Figure 1. The Measurement Model or Confirmatory Factor Analysis (CFA) on IC, CS and PI 


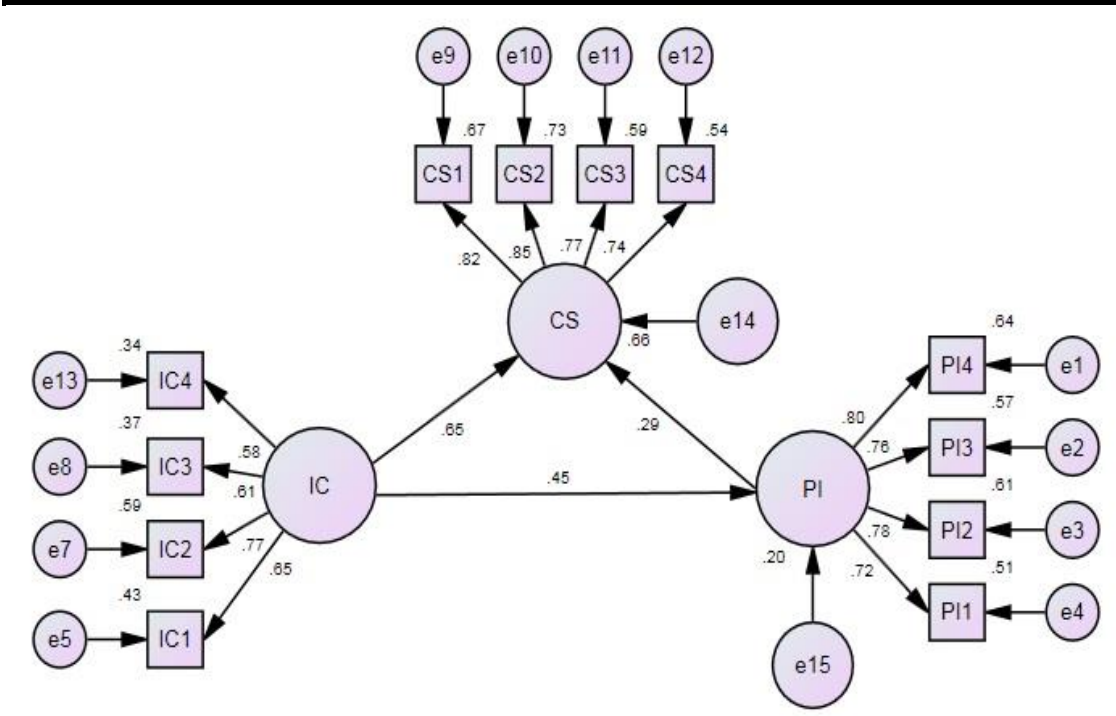

Figure 2. The Structural Equation Model on IC, CS and PI

The path coefficients in Table 6 indicate that IC has a statistically significant relationship with personal interaction and customer satisfaction. PI also remarkably affects CS while IC has significant relationship with CS; therefore, all hypotheses were accepted. In the study, HI where PI is a positive determinant of CS with standardized coefficients as high as .287 meaning that when PI goes up by one standard deviation, CS up by 287 standard deviations. For the H2 IC is a positive determinant of PI with the coefficient is at a high. 449. The least significant path is at H3 where IC is a positive determinant of CS with a coefficient of 645 .

Table 6. Standardized Regression Weight Estimates and Other Statistics

\begin{tabular}{|l|c|}
\hline Description & Estimate \\
\hline $\mathrm{IC} \rightarrow$ PI & .449 \\
\hline $\mathrm{IC} \rightarrow \mathrm{CS}$ & .287 \\
\hline $\mathrm{PI} \rightarrow \mathrm{CS}$ & .645 \\
\hline Chi Square $=84.849$ & \\
$\mathrm{df}=51$ & \\
$\mathrm{p}=.002$ & \\
CFI $=.971$ & \\
TLI $=.962$ & \\
RMSEA $=.055$ & \\
\hline
\end{tabular}




\section{Conclusion}

The fundamental objective of this study was to present and examine the relationships of the theoretical model among the dimensions of "intercultural communication competence", "personal interaction", and "customer satisfaction". The theoretical model presented in the study postulated that "intercultural communication competence" impacts on "customer satisfaction" both directly and indirectly. The model also assumed that "intercultural communication competence" has a positive relationship with "customer satisfaction" and "personal interaction". According to results, the indicated relationships were proven. In the study, intercultural communication competence directly affects personal interaction (.449) and customer satisfaction (.645). There is also indirect effect on customer satisfaction (.129). Additionally, the results of the study provide an empirical evidence that the impact of intercultural communication competence on customer satisfaction through personal interaction.

Several studies have emphasized the significance of intercultural communication competence in marketing context (Baker et al., 2009; Sharma et al., 2009; Reimann et al., 2008); however, empirical examinations of the role of intercultural communication competence in customers' assessments of service practices remain limited. The study has concentrated this insufficiency by intending and examining a cognitive model of the relationships including the constructs of personal interaction, customer satisfaction, and intercultural communication competence. Further studies shall establish on this advance in knowledge regarding other dimension of service quality by examining and purifying the model in other service settings.

The findings also indicated a meaningful improvement in managing and understanding the construct of customer satisfaction in the practice and theory of the retailing. Earlier studies in this area have inclined to adopt a cognitive method by concentrating on particular service quality attributes. Such studies in the industry have attempted to measure generic service scales that effect customer satisfaction, purchase intention, customer loyalty and related topics. In contrast, indeed, the study is the first to have integrated both affective and cognitive factors in an assessment of the relationships including the one of the most important construct of service quality, customer satisfaction, and intercultural communication competence in the context of grocery retail industry. In doing so, the study has confirmed that intercultural 
communication competence plays a significant role in explaining ISEs' interactions.

The findings of the study have numerous implications for further research. First, as noted above, further studies could test both the indirect and direct effects of intercultural communication competence on personal interaction and customer satisfaction in various service settings. Second, it is apparent that the role of intercultural communication competence in the service experience should be one of the greatest interests to scholars and consultants or practitioners. Third, the results of the study recommend that other factors of service quality should be included in further studies.

The main administrative implication from the study is that assessments of service experience should include reference to the intercultural communication competence of the service experience in addition to the conventional cognitive assessment (that is, "service quality"). Most grocery retailers ask customers for cognitive feedback on a variety of service dimensions without recording the negative and positive feelings that customers have experienced during their shopping in the store. The results of this study suggest that management of cross-cultural issues should become a significant issue for providers of grocery retail services. It is apparent from the study that retailers should recognize and pursue to improve the elements of service quality that make the most important contributions to the negative and positive intercultural responses of their customers.

Eventually, as practitioners are well aware, employees play a critical role in defining the delivery of services during the interaction with their customers. Practitioners who wish to place increased emphasis on the significance of their customers' perceptions; expectations and feelings should therefore be performed to efficient controlling of their human resources, particularly their frontline staff, such as cashiers, sales persons. Practitioners may improve the level of education and sequence of training activities for their staffs to ensure that their staffs are completely and precisely aware of the significance of managing and monitoring managing the interaction properly in all ISEs.

There are limitations to the present study. The first limitation is related to the conceptual approach of intercultural communication competence part of the model that was used. In contrast of Sharma's et al. (2009) model, perceived cultural distance of the model were not analysed in the current framework, even though using different items for dimensions in the model may have yielded different findings. The second limitation is related to the empirical study itself. 


\section{İsmet Güneş-Fauziah Sh. Ahmad}

A limited number of responses used as informants in Malaysia, which prevents generalising our findings to the retailing industry as a whole. Nevertheless, our sample is comparable in terms of size with those found in grocery retailing literature based on a qualitative approach in Malaysia. Also, the present research deals with the Malaysian market. Even though modern grocery retailing is not particularly well developed in Malaysia as much as European market, exploring these research questions in other ASEAN countries, or even better, in a multi-country perspective with varying levels of plural form, would be useful. Finally, opportunities for future research consist in testing these initial findings at the retailing level with a quantitative approach in order to see if these advantages are extensively perceived by a larger population of grocery retailers.

\section{REFERENCES}

BABAKUS, E. and BOLLER, G.W. (1992), "An empirical assessment of the SERVQUAL scale", Journal of Business Research, Vol.24 No.3, pp. 253-268.

BAKER, T.L., CRONIN, J.J.Jr. and HOPKINS, C.D. (2009), "The impact of involvement on key service relationships", Journal of Services Marketing, Vol.23 No.2, pp. 114-123.

BITNER, M.J. and HUBBERT, A.R. (1994), "Encounter satisfaction versus overall satisfaction versus quality", in Rust, R.T. and Oliver, R.L. (Eds), Service Quality: New Direction in Theory and Practice, Sage, Thousand Oaks, CA.

BRIONES, E., TABERNERO, C., TRAMONTANO, C., CAPRARA, G.V. and ARENAS, A. (2009), "Development of a cultural self-efficacy scale for adolescents", International Journal of Intercultural Relations, Vol.33 No.4, pp. 301-312.

BOUMAN, M. and VAN DER, W.T. (1992), "Measuring service quality in the car service industry: Building and testing and instrument", Journal of Service Industry Management, Vol.3 No.4, pp. 4-16.

CARO, L.M. and GARCIA, J.A.M. (2007), "Measuring perceived service quality in urgent transport service", Journal of Retailing and Consumer Services, Vol.14 No.1, pp. 60-72.

CHAN, H. and WAN, L.C. (2008), "Consumer responses to service failures: a resource preference model of cultural influences", Journal of International Marketing, Vol.16 No.1, 72-97.

COTTRELL, D.W. (2010). Global Agricultural Information Network. USDA Foreign Agricultural Service.

DABHOLKAR, P.A., DAYLE, I.T. and JOSEPH, O.R. (1996), “A measure of srvice quality for retail stores: Scale development and 
validation", Journal of the Academy of Marketing Science, Vol.24 No.1, pp. 3-16.

DODD, C.H. (1998), Dynamics of intercultural communication 5th edition. MA: Mcgraww-Hill, Boston.

FRIEDMAN, V.J. and ANTAL, A.B. (2005), "Negotiating reality: A theory of action approach to intercultural competence", Management Learning, Vol.36 No.1, pp. 69-86.

GRO"NROOS, C. (1984), "A service quality model and its marketing implications", European Journal of Marketing, Vol. 18 No. 4, pp. 36-44.

HAIR, J., W. BLACK, B. BABIN, ANDERSON R. and TATHAM R. (2006), Multivariate Data Analysis 6th Edition. Prentice Hall, New Jersey.

HOPKINS, S.A., HOPKINS, W.E. and HOFFMAN, K.D. (2005), "Domestic inter-cultural service encounters: An integrated model", Managing Service Quality, Vol.15 No.4, pp. 329-343.

HUDDLESTON, P., WHIPPLE, J., MATTICK, R.N. and LEE, S.J. (2009), "Customer satisfaction in food retailing: comparing specialty and conventional grocery stores", International Journal of Retail and Distribution Management, Vol.37 No.1, pp.63-80.

IHTIYAR, A. and AHMAD, F.S. (2012), "Impact of intercultural competence on service quality and satisfaction in the grocery retailing: a conceptual framework ", International Journal of Science and Management, Vol.1 No.1, pp.13-28.

KONG, M. and JOGARATNAM, G. (2007), "The influence of culture on perceptions of service employee behaviour", Managing Service Quality, Vol.17 No.3, pp. 275-297.

KUO, Y.F., WU, C.M. and DENG, W.J. (2009), "The relationships among service quality, perceived value, customer satisfaction, and post-purchase intention in mobile value-added services", Computers in Human Behavior, Vol.25 No.4, pp. 887-896.

LADHARI, R. (2009), "Service quality, emotional satisfaction, and behavioural intentions: A study in the hotel industry", Managing Service Quality, Vol.19 No.3, pp.308-331.

LUSTIG, M.W., and KOESTER, J. (2009), Intercultural competence: Interpersonal Communication across Cultures 6th edition, Pearson, Boston.

MARTÍNEZ-RUIZ, M.P., JIMÉNEZ-ZARCO A.I. and CASCIO, R. (2011), "Assessing the maximum level of customer satisfaction in grocery stores: A comparison between Spain and the USA", International Journal of Retail and Distribution Management, Vol.39 No.7, pp. 504-521 
MOLINER, M.A., SA'NCHEZ, J., RODRI'GUEZ, R.M. and CALLARISA, L. (2007), "Perceived relationship quality and postpurchase perceived value An integrative framework", European Journal of Marketing, Vol.41 (11/12), pp. 1392-1422.

OMAR, N.A. and MUSA, R. (2011), "Measuring service quality in retail loyalty programmes (LPSQual): Implications for retailers' retention strategies", International Journal of Retail and Distribution Management, Vol.39 No.10, pp.759-784.

PAPPUA, R., and QUESTERB, P. (2006), "A consumer-based method for retailer equity measurement: Results of an empirical study", Journal of Retailing and Consumer Services, Vol.13 No.5, pp. 317-329.

PARASURAMAN, A., ZEITHAML, V.A. and BERRY, L.L. (1985), "A conceptual model of service quality and its implications for future research", Journal of Marketing, Vol.49 No.4, pp. 41-50.

PARASURAMAN, A., ZEITHAML, V.A. and BERRY, L.L. (1988), "SERVQUAL: a multiple-item scale for measuring consumer perceptions of service quality", Journal of Retailing, Vol. 64 No.1, pp. $12-40$.

PASWAN, A.K. and GANESH, G. (2005), "Cross-cultural interaction: comfort and service evaluation", Journal of International Consumer Marketing, Vol.18 No.1, pp. 93-115.

PRASAD, C.J. and ARYASRI, A.R. (2011) "Effect of shopper attributes on retail format choice behaviour for food and grocery retailing in India", International Journal of Retail \& Distribution Management, Vol. 39 No. 1, pp.68 - 86.

PWC (2011). Strong and steady outlook for the retail and consumer products sector in Asia. New York, USA.

REIMANN, M., LUNEMANN, U.F. and CHASE, R.B. (2008), "Uncertainty Avoidance as a moderator of the relationship between perceived service quality and customer satisfaction", Journal of Service Research, Vol.11 No.1, pp. 63-73.

RUST, R.T. and OLIVER, R.L. (1994), "Service quality insights and managerial implications form the frontier", Service Quality: New Direction in Theoryand Practice, Sage, Thousand Oaks, CA.

RYOO, H.K. (2005), "Achieving friendly interactions: A study of service encounters between Korean shopkeepers and AfricanAmerican customers", Discourse and Society, Vol.16 No.1, pp. 79-105.

SHARMA, P., TAM, J.L.M. and KIM, N. (2009), "Demystifying intercultural service encounters toward a comprehensive conceptual framework", Journal of Service Research, Vol.12 No.2, pp. 227-242.

SIZOO, S., PLANK, R., ISKAT, W. and SERRIE, H. (2005), "The effect of intercultural sensitivity on employee performance in cross-

70 | Celal Bayar Üniversitesi Sosyal Bilimler Dergisi - Cilt: 13, Sayı: 2, Haziran 2015 
cultural service encounters", Journal of Services Marketing, Vol.19 No.4, pp. 245-255.

SOLOMON, M.R., SURPRENANT, C., CZEPIEL, J.A. and GUTMAN, E.G. (1985), "A role theory perspective on dyadic interaction: the service encounter", Journal of Marketing, Vol.49 No.1, pp. 99-111.

SOUIDEN, N. and PONS, F. (2009), "Product recall crisis management: the impact on manufacturer's image, consumer loyalty and purchase intention", Journal of Product and Brand Management, Vol.18 No.2, pp. 106-114.

SPAKE, D.F., BEATTY, S.E., BROCKMAN, B.K. and CRUTCHFIELD, T.N. (2003), "Consumer comfort in service relationships: Measurement and importance", Journal of Service Research, Vol.5 No.4, pp. 316-332.

Statistics Department of Malaysia (2010) http://www.statistics.gov.my/portal/index.php?option=com content andview=articleandid=1215\%3Apopulation-distribution-and-basicdemographic-characteristic-report-population-and-housing-censusmalaysia-2010-updated-2972011andcatid=130\%3Apopulationdistribution-and-basic-demographic-characteristic-reportpopulation-and-housing-census-malaysia-2010andlang=en, (Accessed: 29 May 2012).

SURPRENANT, C.F., MICHAEL, R.S. and GUTMAN E.G. (1983), "Service encounters are human interactions", Journal of Business Research, Vol.20 (January), pp. 13-21.

THOMAS, D.C., ELRON, E., STAHL, G., EKELUND, B.Z., RAVLIN, E.C., CERDIN, J.L, POELMANS, S., BRISLIN, R., PEKERTI, A., AYCAN, Z., MAZNEVSKI, M., AU, K. and LAZAROVA, M.B. (2008), "Cultural intelligence: Domain and assessment international", International Journal of Cross Cultural Management, Vol.8 No.2, pp. 123-143.

WALL, T.D. and PAYNE, R. (1973), "Are deficiency scores deficient?", Journal of Applied Psychology, Vol.58 No.3, pp. 322-326.

WANG, Y.J., DOSS, S.K., CHIQUAN GUO, C. and LI, W. (2010), "An investigation of Chinese consumers' outshopping motives from a culture perspective: Implications for retail and distribution", International Journal of Retail \& Distribution Management, Vol. 38 Iss: 6, pp.423 - 442

WIGLEY, S. and RACHEL CHIANG, C.-L. (2009), "Retail internationalisation in practice: per una in the UK and Taiwan", International Journal of Retail \& Distribution Management, Vol. 37 No. 3 , pp. $250-270$. 
72 | Celal Bayar Üniversitesi Sosyal Bilimler Dergisi - Cilt: 13, Sayı: 2, Haziran 2015 